\title{
Global Biomedical Waste Management Issues and Practices
}

\author{
Mohammed Noor Shaida, Sandeep Singla
}

\begin{abstract}
Biomedicalwaste is a special type of waste which carries high potential of infectionand injury. Hospital waste management means the management of waste produced by hospitals using techniques that will check the spread of diseases through hospital waste. This study was conducted to examine healthcarewaste management practices in different hospitals. The related data has been collected from various international journals, books and websites. The data is analyzed by finding biomedical waste management issues and challenges around the world by gap analysis. Hospital waste generation, segregation, collection, transportation anddisposal practices were not in accordance with standard guidelines. The average waste generation in most of the hospitals was almost equivalent to other under developed countries but less than that of developed countries. Conclusions: The hospital waste in the majority of hospitals was mismanaged. No properhospital waste management plan existed has been done except at few hospitals.In this research the analysis of current biomedical wastes management, and some steps for management of healthcare is proposed.
\end{abstract}

Keywords:Biomedical waste management, generation, segregation, disposal, guidelines

\section{INTRODUCTION}

The biomedical wastes (BMW) are defined as hazardous and infectious in nature which has direct effects on the sounding environment in comparison to the municipal wastes. Around 10 to $25 \%$ of the hospital wastes are hazardous and infectious that will cause of many diseases such as HIV, Hepatitis etc. therefore, the activities of healthcare waste management will protect health and saving lives [ICRC, 2011]. BMW can be defined as all types of waste such as liquid and solid waste generating during the treatment, diagnosis and operations of human being and animals; which all of them are infectious and hazardous waste. The solid waste within the hospitals can be categorized as $85 \%$ of general waste (municipal waste), $15 \%$ biomedical waste, $10 \%$ infectious waste and the remained $5 \%$ are chemical and radioactive waste. The and infectious wastes and after that the ashes go to the secure landfill[HWM guideline, 2018].

Revised Manuscript Received on June 15, 2019.

Mohammed Noor Shaida, Sandeep Singla, RIMT University, Punjab, India reasons that the BMWbecoming important are (a) injuries of hospital waste handles and personals by sharps with infected by different types of infections (b) patient are infected regarding to poor management of BMWin the hospitals (c) the risk of BMWinfectious, hazardous and chemical also recorded at the outside of hospitals to public which are living around, the handlers and scavengers (d) and the risk of environmental pollution (air, water and soil pollution) due to poor recycling, treatment and disposal of BMW [Gupta et al, 2018].

Cytotoxic are kinds of drugs that using as primary treatment of cancers. These drugs are high toxic to cells because of cell reproduction throughtheir action and have proved that most of them are carcinogens and mutagens or teratogens. Patient by using the drugs (therapeutic doses) will presented an extended list of acute and chronic adverse effects including cancers. Therefore, it high risk of exposure to the worker who are in contact with cytotoxic drugs and relevant wastes. The cytotoxic waste is using in healthcare facilities, veterinary clinics, laboratories and research centers [Queensland Government, 2018].

According to the guideline management of BMW rules, 2016, the segregation, collection, storage, transportation and disposal are the most important steps forbiomedical wastes management(BMWM) in the hospitals. It is responsibilities hospital to manage the segregation of waste at the sources of generation manually or by colour coded containers or bins. The general solid waste must not be mixed with BMW in the overall waste stream. The BMW which is stored in the in hospital shall be transported within 24 to 48 hours. The special types of infectious waste such laboratory waste need an onsite pretreatment before disposal. For improving the BMWM for all types of waste segregation provide coded colour bags before final disposal. The incineration is a pretreatment option for hazardous.

\section{A. Sources of Biomedical wastes}

Based on training Component of the Project "Environmentally Sound Management of Medical Wastes in India" on 2018, the main sources of healthcare waste generation are as follows:

1. Hospitals

2. Nursing homes

3. Clinics

4. Medical laboratories

5. Blood banks 
Global Biomedical Waste Management Issues and Practices

6. Mortuaries

7. Medical research and training centers

8. Biotechnology institution/production units

9. Animal houses etc.

10. Such a waste can also be generated at home if health care is being provided there to a patient (e.g. injection, dressing material etc.)

\section{B. Biomedical waste Characteristics}

According to the study of Training manual on biomedical waste management for doctors, nurses, nodal officers and waste managers in India on 2018, the important of biomedical waste management rules and regulations, understanding the salient features of application definitions

and duties of the healthcare provider, the segregation, packaging, transportation, storage, treatment and disposal options prescribed under the new biomedical waste management rules on 2016 and finally to know the salient differences between biomedical waste management and handling rules 1998 and 2016. The components of hazardous waste at healthcare are show in table.1. All

individuals (generators, handlers and exposed group) that working with BMW are at health risk. The main groups that are at risk are nurses, doctors, laboratory technicians, patients receiving care either at hospital or at home, visitors to hospitals facilities, cleaners and laundry services. Moreover, general public in case of improperly managed BMW, the personnel working in waste treatment, management and disposal facilities and personnel involving in transportation of BMW. According to the study of Training manual on biomedical waste management for doctors, nurses, nodal officers and waste managers in India on 2018, the BMWM processes begin from minimization, segregation at sources up to treatment and final disposal. The important component behind of this lifecycle approach is worker safety, patient safety and environment safety. Regarding to the types of waste mentioned in table. 1 all generated wastes at hospitals need to manage into four bins (yellow, red, white and blue) in storage and treated[Training Manual, 2018].

Table. 1 classification of biomedical waste as per BMWM rules 2016

\begin{tabular}{|c|c|c|}
\hline $\begin{array}{l}\text { Colour } \\
\text { Coding }\end{array}$ & Types of Waste & Examples \\
\hline Yellow & $\begin{array}{l}\text { a. Human anatomical waste } \\
\text { b. Animal anatomical waste } \\
\text { c. Soiled waste } \\
\text { d. Expired to discarded medicine } \\
\text { e. Chemical waste } \\
\text { f. Chemical liquid waste } \\
\text { g. Discarded linen, mattresses, } \\
\text { bleedings contaminated with } \\
\text { blood or body fluid } \\
\text { h. Microbiology, biotechnology and } \\
\text { other clinical laboratory wastes }\end{array}$ & $\begin{array}{l}\text { a. Human tissues, organs, body parts, fetus } \\
\text { b. Experimental animal carcasses } \\
\text { c. Cotton contaminated with blood and other body fluids, } \\
\text { plaster casts } \\
\text { d. Discarded tablets and capsules } \\
\text { e. Used or discarded disinfectants chemicals used in } \\
\text { biologicals } \\
\text { f. Laboratory reagents, X ray film developer, disinfectants, } \\
\text { g. Bedsheets, blankets, mattresses contaminated with blood } \\
\text { h. Culture plates, blood bags or body fluids }\end{array}$ \\
\hline Red & Contaminated waste (recyclable) & $\begin{array}{l}\text { i. Plastic tubings, urine bags, vacutainers, gloves, catherters, } \\
\text { Ryle's tube }\end{array}$ \\
\hline White & j. Waste sharps including metals & $\begin{array}{l}\text { j. Hypodermic needles, auto disabled syringes, syringes } \\
\text { with fixed needles. Scalpels, knives, blades, lumber } \\
\text { puncture needles and intravenous needles. }\end{array}$ \\
\hline Blue & $\begin{array}{l}\text { k. } \text { Glassware } \\
\text { 1. } \quad \text { Metallic body implants }\end{array}$ & $\begin{array}{l}\text { k. Used glass bottles } \\
\text { 1. } \quad \text { Body implants, plates and screws. }\end{array}$ \\
\hline
\end{tabular}

Source: Training manual on BMWM for doctors, nurses, nodal officers and waste managers in India on 2018.

\section{OBJECTIVES AND}

The main purpose of the research is to discover the present global biomedical waste management (BMWM) issues and practices. The focus is on the problems and challenges regarding to the existing BMWM practices in healthcare facilities by considering of multiple perspectives of researches. This research is theory basedand will review the secondary data from different reliable and trustable international journals. Then the data will be analyzed by finding gaps and issues related to the BMWM globally. Therefore, based on existing research gaps, a proper management system established on international rules of
BMWM will be proposed. The research will be over by conclusion and recommendations.

\section{BMWM ISSUES}

In Soyam et al. (2017) summarizing article on studying of BMWM among health care workers in a rural hospital in Delhi, that the finding of level of worker's knowledge, altitude and practices about hospital wastes management were

Published By: 
the main purposes of the research. The study area of this research was 155 BMWin rural hospitals in Delhi. These questionnaires were distributed and collected from 155 hospitals. The collected data was analyzed by using SPSS-17. The finding shown that almost $97.4 \%$ of healthcare waste workers were aware of roles and regulations of BMWM and they have positive attitude. The practice of BMWworkers according to BMWM was relatively poor. This study found that the worker had good attitude but the knowledge and practices were poor in BMWM. Therefore, the most of them are at the risk of exposure regarding to handle of BMW. This research proposes an effective programme to improve the worker's groups, nurses and paramedical staff knowledge, attitude and practices.

According to the study on BMWM in Ghana on 2016, presently for management and safe disposal of medical waste there is no legislation to provide guidance and enforcement for health facilities in Ghana. Therefore, it caused that each health facility for managing and disposal of medical waste decides independently which widely risk to public health and environment. The Environmental Protection Agency (EPA) of Ghana by the collaboration of Ministry of local government and rural development published guidelines for how the institutions should manage the biomedical waste disposal. They recommended using of different colored containers and bags such as black for general waste, yellow for infectious waste and brown for hazardous waste management and disposal. However, all hospital facilities in Ghana follows these guidelines. To know how the hospitals, manage the BMW according to guidelines, on 2014 tried to study the two largest hospitals in Accra, The Korle $\mathrm{Bu}$ Teaching Hospital and the Ridge Regional Hospital. In the Korle $\mathrm{Bu}$ hospital, the findings show that only one of brick incinerator out of three and one mechanical incinerator out of two existing were operational. And $20 \%$ of solid waste were separated by coloured bags at sources, and all types of waste ended up in the same landfill (disposal site). The bags were questionnaires were excluded during the analyzing process for insufficient data reasons and finally 73 questionnaires which is $76 \%$ of the questionnaires were distributed. Descriptive and analysis statistics technique is used in this study and also the theories are tested as well. The results of research showed governmental BMWM instruction have given to the most of hospitals in Jordan. The percentage achieved by the research is $98.6 \%$ and also the samples were about $94.5 \%$. The study showed that the hospitals having instruction of medical waste management and the worker and nursing staff are understanding the instructions. The

maternity and child care and 13 epidemic presentations on 2012. There were 26900 sickbeds in hospitals and health centers that $85 \%$ of them leading position in the provincewhich generating more medical wastes. The data were collected from government websites, published papers and the method was semi-structured interview which is given full flexibility and creativity in interview. The interview was designed to ask questions base on nation BMWM regulations (2003) and World Health Organization (1999). The responses were 20 officials and managers, 20 doctors and nurses and opened by wildlife and the supervision staff sacrificed protective equipment. However, at the Ridge hospital, the solid waste segregated at source by coloured bags and containers as required, but pay for a collection services of solid waste collection company which after leaving the hospital all waste disposed in the same place in the landfill. This study also conducted on four hospitals out of twelve in the Offinso municipality of the Ashanti which show that poor BMWM challenges in the country. The BMW were disposed in open dump site without fences or pits or openly were burned. Therefore, heath risk of current disposal methods are impacts of sharps and infectious wastes, impact of chemical and pharmaceutical wastes and impacts of radioactive wastes on those who works and do services in healthcare facilities such as doctors, nurses, pharmacists, laundry, waste handling, waste transportation staff and scavengers. Finally, this research recommended that the policy and legislative instrument on medical waste management in Chana, centralized Healthcare Waste Collection, Transportation, Storage, Treatment and disposal facilities, collection, storage and transportation, treatment, destruction and final disposal can be the solution for this badly condition of waste management in these hospitals (Imani Centre for policy and education, 2016).

Based on research of Efficiency of BMWM performance, health sector and its impact on environment in Jordan applied study on 2012, given an idea about BMWM in medical services and their impact on the environment in Jordan. The purposes of this study were safe and secure management of hazardous wastes which is include of segregation at sources, classifying, collection, processing and reduce their effect on the local community. To achieve the objectives, researcher referred to distribution of scientific questionnaires and developed based on the previous studies.Among the 101 hospitals, 96 questionnaires were distributed but only 78 questionnaires recovered, five

researchrecommended to: Commitment of the hospital to apply the rules and regulations of the BMWM and to increase the focus on the training program of the stuff and employees[Al-Habash and Al-Zubi, 2012].

According to the case study on BMWM in Xinxiangof China by Agricultural University in Beijing and Xinxiang Medical University in Xinxiang on 2014, which Xinxiang located in the north of Henan province was the area of study by 8249 square kilometersand the population was 5.7 million on 2012 . The research found that 719 healthcare institutions including $247 \quad$ hospitals, 12 230 workers in hospitals and BMW disposal centers. The researcher found the workers more positive than the other by responding rate of $93.33 \%$, while the other responding rate was $82 \%$. The medical waste management goal is to realize the harmlessness, reducing and recycle of BMWM. In Xinxiang,

BMWMregulations have developed to make ensure suitable processing healthcare waste; but

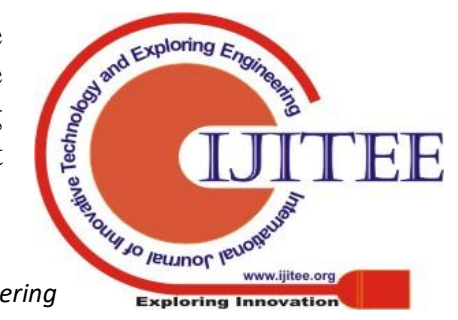

DOI: 10.35940/ijitee.I1 169.0789S19
1055 Blue Eyes Intelligence Engineering

\& Sciences Publication 
currently some challenges such as lack of awareness, low information, ineffective enforcement, poor segregation and disposal method, uneven fees distribution, cost of collection is high are exist in country as well as in towns. In order to manage the current issues of medical waste streams in Xinxiang town some recommendations are proposed according to integrated BMWM system. The management system is including of quantitative and evaluation regulations, macro control system, a database platform of management and recycling network in some remote areas (Qiao, Nie and $\mathrm{Wu}, 2014)$.

According to the study of waste management in Hospitals, case project with Ecosir Oy and Eksote on 2016, the thesis propose was evaluation of the current BMWM situation and find out solutions by assisting of a case study project. The Ecosir Group Ltd and Eksote were the case companies involve in the project for evaluations of current hospital's waste and laundry management in South Karelian. The collected data was from both theoretical of literature of online books and empirical results of the case project. The thesis theoretical part was focusing on answering of whyBMWMin wise to keep in good control condition. And the empirical part of the thesis was focusing on given ideas that how to improve this condition and give and case example. The case project of waste at South Karelia Central Hospital study shown that there is no mechanical machinery to assist and there are not sufficient workers to focus on the waste transportation within the hospital. The first step waste assessment of hospital's waste management rooms, the hospital staff were involving in collection of wastes from wards, transporting of trash bags into these rooms and waste containers. The transported wastes were containing of bandages and bloody cloths, sharps and needles which is distributed into different wastes container for making easy to recycle safely. However, there was a set of rules and regulations in order to remove the wastes from rooms but there are some mishaps resulting injuries among the staff who handle the wastes in this hospital. The second steps of the project investigation covered the transportation of wastes from storage rooms to the loading location of the hospital which was the large containers and compressors. The responsible staff was transporting manually to the end point. The final step of waste management at South Karlia central hospital process for is the responsibility of the hospital in distribution of wastes at the final point. The mentioned hospital for BMWuses normal sorting by colored bags; that orange and back bags are used for management of energy and common wastes respectively. Therefore, regarding to the BMWM going on at the South Karelia's hospital some possible solutions proposed. (1) the waste rooms space need to make around the hospital (2) construction of more elevator for wastes transportation to do not much the patients time of movements (3) the waste should be transporting rapidly from storages rooms because currently the waste stays too long the rooms (4) waste handling manually mechanism is physically depleting [Melanen, 2016].

\section{GAP ANALYSIS}

The brief gaps and problem associated with the HWM practices are poor collection and treatment, financial and facilities constrains, awareness and training, lack of indistinct role of local authorities, and responsiveness to the health and environmental concern. The lack of awareness and training among the hospitals affected to inappropriate handling and processing of $\mathrm{HW}$ which is high risk on the staff involving in the HWM stream. The authority does not supervise and monitor regularly from the hospitals (government and private) based on national/international BMW rules. The all given hand to hand which made the BMWM more problematic and complication. Therefore, regarding to the reviewed gaps and problems of BMWM in the most hospitals, an appropriate BMWM is mandatory to overcome the current issues and challenges.

\section{BIOMEDICAL WASTE MANAGEMENT}

\section{A. Segregation}

Based on the biomedical waste management rule of 2016, the BMW facilities essential segregation on time of and at source of generation by using coded colour bags and containers. The collection and accumulating the BMW need to perform under control and supervise ring of doctors, nursing staff and who is responsible for. The collection points and the number of colour coded plastic bags should be enough in compare to whole hospital wards. Four categories of colour coded bags are yellow, red, white and blue for BMWM as presented in details in Table.1 and also presented in figure.1 (BMWM guideline, 2018).

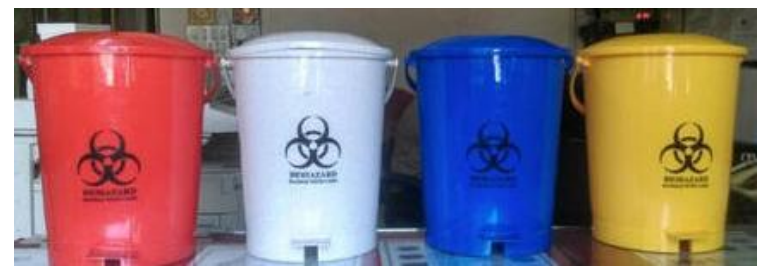

Figure.1 Four categories of colour coded bags: yellow, red, white and blue bins

Source: https://www.indiamart.com/proddetail/colour-codedwaste-bins-for-biomedical-and-solid-waste-management$\underline{19481875762 . h t m l}$

\section{B. Collection}

The HW collection process are as follow: (a) The BMW collection system should be based on daily from all wards of hospital in the arranged intervals of time. Based on BWM rule 2016 the human and animal anatomical waste, biotechnology waste and soiled waste are mast be disposed within 48 hours; and also the general solid waste should be collected in the same time with BMW. The time of collection must be considered BMWM to do not much the rush time of visitors coming in hospital. (b) the bags and sharps containers should not be packed more than $2 / 3$ of full, replace new Published By: 
one and then apply tags to make them ready for collection. The coded colour plastic bags should be printed with the symbols, date, types and quantity of BMW as well as receiver's information to the waste can be directed to treatment or disposal points. (c) to increase the effectiveness of HWM collection and storages, all types of used bags, bins and containers in are essential to be labeled with Bio-Hazard and Cytotoxic-Hazard symbols. (d) the BMW must be stored in planned place far from patient and visitor paths[BMWM guideline, 2018].

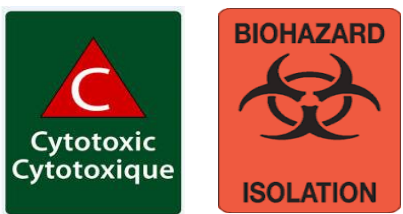

Figure.3Cytotoxic-Hazard symbol and Biohazards symbol

Source: https://www.megapixl.com/hazard-warning-signbiohazard-illustration-15392155

\section{Transportation}

The transportation of BMW from the designated storage points will be performing by closed top trolleys and wheels facilities containers for easy and convenient movement. The capacity of the trolleys and carts need to be equal to the waste generating in each wards. Reasonable and crowded visitors and patient routs mast be selected for BMW transportation trolleys and carts. The routes mast not be assigned trough the high risk wards and areas. And the transportation routes and supplying routes should be separated within the hospital. The routes access condition should be convenient for all wards and generation points [BMWM guideline, 2018].
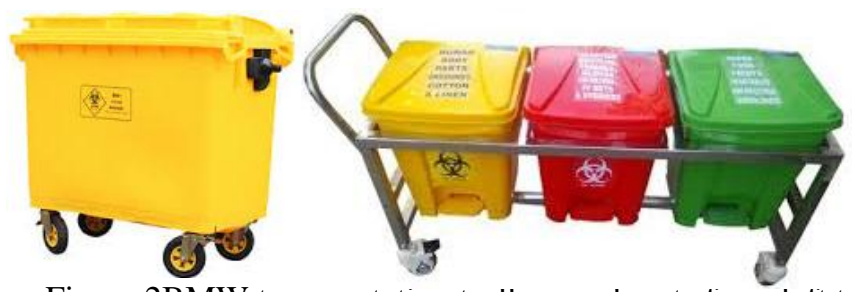

Figure.2BMW transportation trolleys and carts trom lett to right respectively

Source:http://famedhca.wholesale.airmaxssale.com/pz6f55d2 a-11001-medical-waste-bin-medical-waste-trolley-spillcontrol-bin.html

\section{Disposal of BMW}

\section{a. Shredding}

The BMW such as plastics (syringes, catheters etc.), sharps (needles, glasses, blades etc.) are going to shredding process after chemical pretreatment.

\section{b. Autoclaving Technology}

The autoclaving technology is a standard treatment process for disinfecting reusable equipment in the healthcare facilities. The water boiling temperature is raising to the more $100{ }^{\circ} \mathrm{C}$ for the saturation condition. Then the autoclave method operates under this condition for disinfecting of reusable instrument.

\section{E. Incineration Method}

Incinerator is more hygienic method for management of BMW recommended for all hospitals; this system work by combustingat high temperature and convert the waste tosome emissions (gasses) and ashes bydecreasingthe volume of wastes up to $90 \%$. There are three types of incinerator regarding to using (1) controlled air, (2) excess air and (3) rotatory kiln. The first step of incinerator is for feeding the waste called primary chamber, the part mast not be designed for manual handling and charging of BMW wastes. The automatic feeing tools for the primary chamber is recommended for the intervals that become facilitated for ensuring of not direct impact of exposure on operators. The temperature of burningBMW in the primary chamber is higher than $850{ }^{\circ} \mathrm{C}$ and in the secondary chamber around $750^{\circ} \mathrm{C}$. the emission gases are leading to the air without leakages in flue and having automatic emergency vent in case of leaking. In most of the incinerators the flue air treating to $90 \%$ according to the national environment emission laws. The produced ashes from incinerator dispose to secure landfill[Central Pollution Control Board, 2017].

\section{F. Landfill disposal method}

Landfill disposal is one of the most using method for HWM in the world. The landfill which is using for disposal of BMW mast be secure landfill with single or double composite linear systems. Because the BMW waste cannot be disposed to the municipal landfill. (1) The landfill system which using for BMWM mast meet all criteria of Hazardous landfill sites. (2) in the area that has more rainfall and the level groundwater is between $2 \mathrm{~m}$ to $6 \mathrm{~m}$ double composite liner is suggested. (3) single composite liner has $30 \mathrm{~cm}$ or more layer for leachate collection, the HDPE thickness is $1.5 \mathrm{~mm}$ or even more and $150 \mathrm{~cm}$ of clay soil compacting to decrease the permeability of foundation. (4) for double composite liner, two composite liners is used with two separated layer soil each $30 \mathrm{~cm}$ and 45 $\mathrm{cm}$ between the liners. (5) leachate drainage system for collection and treatment purposes. (6) management of gaseous emitting from landfill trough network of pipes, and treating and combusting to convert in carbon dioxide. (7) final covering $60 \mathrm{cmon}$ the top of the landfill by several layers to protect penetration of rain and emission of gaseous from the landfill. (8)environmental monitoring is needed to control the air, soil, surface and ground water sources [Central Pollution Control Board, 2010].

\section{TRAINING PROGRAM}

Based on BMWM guideline on 2018, the training for hospital staff are involving in handling and processes for at least annually or for new employed staff. The training parameters will cover the theoretical knowledge, demonstration 


\section{Global Biomedical Waste Management Issues and Practices}

of handling of BMW methods and practical implementation[HWM guideline,2018].

\section{CONCLUSIONS AND RECOMMENDATIONS}

According to the research study, the current BMWM practices in the most of the countries is very week and not pleasing. The BMWM weakness are lack of segregation at source, proper collection system, storages points, transportation system and disposal. The most of hospital do not follow the biomedical waste guidelines and rules, the most of their staff and who are handling waste are not trained to protect themselves as well as patients and visitors from infectious and hazardous waste. Moreover, the disposal sites are not sited according to the BMWM rules which is caused health and environmental pollutions. Therefore, BMWM is a globalissuewhich urgent need to manage and control by implementation of BMWM rules 2016.

Based on the research study the following are recommended for BMWM:

- For all of healthcare centers is essential to control and minimize the quantity of BMW producing throughestablishing of the reduce, reuse and recyclingat source at all hospitals.

- The municipality and environmental headquartersdevelopsupervising and monitoring plan for BMWM streams.

- The awareness programs will be effective and motivated for doctors, nurses, employers and even for patient and visitors to minimize the risk of infected and hazards wastes.

- As final recommendation all BMWM hierarchy mast be carefully assessed to decrease the inverse impacts of toxic on environment.

\section{REFERENCES}

1. Al-Habash. M and Al-Zubi. 2012. Efficiency of medical waste management performance, health sector and its impact on environment in Jordan applied study. Al-Balqa' Applied University, Amman University College, Amman-11118- Jordan. World applied Sciences Journal 19 (6): 880-893, 2012, ISSN 1818 - 4952 @ IDOSI Publications, 2012. DOI: 10.5829/idosi.wasj.2012.19.06.2775

2. Biljana ShikoskaCena. Dimova, Gjorgji Schumanovand Vlado Vankovski. 2016. biomedical waste management. Mac Med Review 2016; 70(1): 1-8. DOI:10.1515/mmr-2016-0001. Retrieved on April 11. 2019 from

3. Central Pollution Control Board. 2017. Protocol for Performance Evaluation and Monitoring of the Common Hazardous Waste Treatment Storage and Disposal Facilities including Common Hazardous Waste Incinerators. Ministry of Environmental and Forest. Parivesh Bhawan, East Arjun Negar, Delhi-110 032. Retrieved on May 25. 2019 from http://cpcb.nic.in/displaypdf.php?id=aHdtZC9SZXZpc2VkX0d1aWRlb GluZXNfZm9yX0Jpby1tZWRpY2FsX1dhc3R1X0luY2luZXJhdG9yLn $\mathrm{BkZg}==$

4. Gupta. R. 2018. Manual for biomedical waste management. Government Medical College and Hospital - 32, Chandigarh. Retrieved on May 25. 2019

fromhttps://www.worksafe.qld.gov.au/_data/assets/pdf_file/0006/88710 /guide-handling-cytoxic-drugs-related-waste.pdf

5. HWM guideline. 2018. Guideline for Management of Healthcare waste as per biomedical waste management rules, 2016. By Directorate general of Health Services Ministry of Health and Family Welfare and Central Pollution Control Board Ministry of Environment, Forest and Climate Change. Retrieved on May 25. 2019 from http://cpcb.nic.in/uploads/hwmd/Guidelines_healthcare_June_2018.pdf

6. ICRC. 2011. Biomedical waste management. International committee of the Red Cross, 1202 Geneva, Switzerland, November 2011. Retrieved on May 25. 20192 from https://www.icrc.org/en/doc/assets/files/publications/icrc-002-4032.pdf

7. Imani Centre for policy and education. 2016. Biomedical waste management in Ghana. East Legon, Accra, Ghana, March 4.2016. Retrieved on February 20. 2019 from http://www.imaniafrica.org/wpcontent/uploads/2016/05/BIOMEDICAL-WASTE-MANAGEMENTIN-GHANA.pdf

8. Melanen. M. 2016. Waste Management in Hospitals, Case project with Ecosir Oy and Eksote. Saimaa University of Applied Sciences, Faculty of Business Administration Lappeenranta, International. Bachelor's Thesis. Retrieved on March 06. 2019 from https://www.theseus.fi/handle/10024/116209

9. Pandey. A, Ahuja. S, Madan. M and Asthana. A. K. 2016. Bio-Medical Waste Management in Tertiary Care Hospital: An Overview. Journal of Clinic and Diagnostic Research. Retrieved on March 12. 2019 from 10.7860/JCDR/2016/22595.8822

10. Qiao. Z, Nie. L and Wu. H. 2014. Medical Waste Management in China: Case Study of Xinxiang. China Agricultural University, Beijing and Xinxiang Medical University, Xinxiang, China. Copyright (c) 2014 by authors and Scientific Research Publishing Inc. This work is licensed under the Creative Commons Attribution $\begin{array}{llll}\text { International License } & \text { (CC }\end{array}$ http://creativecommons.org/licenses/by/4.0/

11. Queensland Government. 2018. Guide for handling cytotoxic drugs and related waste. Office of industrial relations, Workplace Health and Safety Queensland. PN10522 Version 4. Retrieved on June 05. 2019 from

https://www.worksafe.qld.gov.au/_data/assets/pdf_file/0006/88710/gui de-handling-cytoxic-drugs-related-waste.pdf

12. Soyam1. G. C, Hiwarkar1. P. A, Kawalkar1. U. G, Soyam. V. C, Gupta. V. K. 2017. KAP study of bio-medical waste management among health care workers in Delhi. International Journal of Community Medicine and Public Heal, th. Soyam GC et al. Int J Community Med Public Health. pISSN 2394-6032 | eISSN 2394-60402017 Sep;4(9):3332-3337

13. Training Component of the Project "Environmentally Sound Management of Medical Wastes in India" Endeavour of GEF, UNIDO, MoEFCC and State Governments of Gujarat Karnataka, Maharashtra, Odisha and Punjab, First Published 2018, by the United Nations Industrial Development Organization. Retrieved on February 22. 2019 from

http://envfor.nic.in/sites/default/files/5.\%20Waste\%20handlers\%20manu al_FLIP\%20CHART.pdf

14. Vasistha. P, Ganguly. R, Gupta. A. K. 2015. Questionnaire Method for Assessing Biomedical Waste Management in Shimla City-Case Studies of Public and Private Hospitals. Journal of Civil Engineering and Environmental Technology. p-ISSN: 2349-8404; e-ISSN: 2349-879X; Volume 2, Issue 16; October-December, 2015 pp. 11-14, Krishi Sanskrit Publications.

\section{AUTHORS PROFILE}

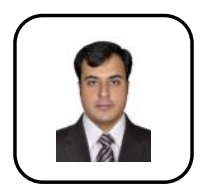

Mohammad Noor Shaida received his B.Tech in Civil Engineering in 2004, Engineering faculty, Herat University, Herat, Afghanistan. M.Tech from Environmental Engineering Management on Feb 2012 from Asian Institute of Technology (AIT), Thailand. He is $\mathrm{Ph}$. D research Scholar in the Civil department at School of Engineering and Technology, RIMT, Punjab, India. He is presently working as an Associated Professor at Civil department, Engineering Faculty, Herat University and he is member of Herat Municipality advisory board, Herat city, Afghanistan. He has 15 years' experiences of academic and construction management in Afghanistan. He has published 9 papers in in various reputed journals. His research interest includes environmental engineering, waste management, water sesgurxploning fagement, water supply and geotechnical engineering.

Published By:

1058 Blue Eyes Intelligence Engineering \& Sciences Publication 


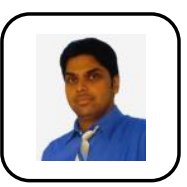

Dr. Sandeep Singla received his B. Tec degree in Civil Engineering in 2001 from Punjab Technology University, Jalandhar. M. Tech from Thapar Institute of Engineering and Technology, Patiala in 2004 and $\mathrm{PhD}$ degree from National Institute of Technology (NIT) Kurukshetra in 2018. Presently, he is working as Professor and Head in Department pf Civil Engineering, RIMT University, Punjab, India. He has published more than 60 papers in National and International Journals/Conferences. He has guided more than $30 \mathrm{M}$. Tech Thesis. Besides being member of board of studies in various universities, he is a life member of ISTE and also member of IEI. His research interests include environmental engineering. Waste management, concrete technology, artificial intelligence, remote sensing and GIS. 